\title{
The evolution of the concept of stress and the framework of the stress system
}

\author{
Siyu Lu ${ }^{1}$, Fang Wei ${ }^{1,2, *}$ and Guolin $\mathrm{Li}^{1,2,3, *}$ \\ ${ }^{1}$ Center for Aging Biomedicine, Key Laboratory of Protein Chemistry and Developmental Biology of Fish of Ministry of Education, \\ College of Life Sciences, Hunan Normal University, Changsha, Hunan 410081, China. \\ 2 National \& Local Joint Engineering Laboratory of Animal Peptide Drug Development, College of Life Sciences, Hunan Normal Univer- \\ sity, Changsha, Hunan 410081, China. \\ ${ }^{3}$ Key Laboratory of Hunan Province for Model Animal and Stem Cell Biology, School of Medicine, Hunan Normal University, Chang- \\ sha, Hunan 410081, China. \\ * Corresponding Authors: \\ Guolin Li, Hunan Normal University, 36 Lushan Road, Changsha, Hunan 410081, China; E-mail: hnsdlgl@hunnu.edu.cn \\ Fang Wei, Hunan Normal University, 36 Lushan Road, Changsha, Hunan 410081, China; E-mail: weifang2019@hunnu.edu.cn
}

\begin{abstract}
Stress is a central concept in biology and has now been widely used in psychological, physiological, social, and even environmental fields. However, the concept of stress was cross-utilized to refer to different elements of the stress system including stressful stimulus, stressor, stress response, and stress effect. Here, we summarized the evolution of the concept of stress and the framework of the stress system. We find although the concept of stress is developed from Selye's "general adaptation syndrome", it has now expanded and evolved significantly. Stress is now defined as a state of homeostasis being challenged, including both system stress and local stress. A specific stressor may potentially bring about specific local stress, while the intensity of stress beyond a threshold may commonly activate the hypothalamic-pituitary-adrenal axis and result in a systematic stress response. The framework of the stress system indicates that stress includes three types: sustress (inadequate stress), eustress (good stress), and distress (bad stress). Both sustress and distress might impair normal physiological functions and even lead to pathological conditions, while eustress might benefit health through hormesis-induced optimization of homeostasis. Therefore, an optimal stress level is essential for building biological shields to guarantee normal life processes.
\end{abstract}

doi: $10.15698 /$ cst2021.06.250

Received originally: 30.12 .2020

in revised form: 14.04.2021,

Accepted 19.04.2021,

Published 26.04.2021.

Keywords: stress, homeostasis, concept, definition, eustress, distress, sustress.

\section{Abbreviatons:}

GAS - general adaption syndrome, HPA - hypothalamic-pituitary-adrenal, ROS - reactive oxygen species.

\section{INTRODUCTION}

Over the past decades, the concepts of stress have evolved and expanded significantly. Although the current concept of stress is developed from the pioneering contributions of Claude Bernard [1], Walter B. Cannon [2], and Hans Selye [3], stress no longer specifically refers to the acute activation of hypothalamic-pituitary-adrenal (HPA) axis and a series of compensatory sympathoadrenal responses when homeostasis is threatened [2,3]. It is now clear that even lower organisms or isolated tissues and cells also have stress responses $[4,5]$. Meanwhile, with the specifying of the concept of homeostasis, the concept of stress is becoming more and more specific. For instance, oxidative stress specifically refers to a disruption of redox signaling and control $[6,7]$, and endoplasmic reticulum stress refers to the stress induced by the accumulation of unfolded proteins in the endoplasmic reticulum [8]. With the extension of the concept of homeostasis, the concept of stress has permeated our culture in many aspects, it has become a core concept in the field of biology and medicine, and has been widely used in psychological, physiological, social, and environmental fields.

The implications of stress have expanded greatly. It now includes not only the negative aspects such as "general adaptation syndrome (GAS)" defined by Selye, threats to health and life, but also the positive aspects such as adapting to the existing environment and anticipating future challenges. Therefore, even Selye also suggests that it 
should be better to categorize stress into "eustress" meaning good stress, and "distress" meaning bad stress [9]. However, many scientists still use Selye's "GAS" to define stress, and simply interpret stress as a threat to health. An important reason for this is that the concept of stress itself has not been uniform. As Selye said, the concept of stress is often confused with the concept of stressful stimulus, stressor, stress response, and stress effect [9].

Therefore, this paper will first construct the basic framework of the stress system, and then summarize the key developments that have contributed to shaping the framework. Through this way, we hope the mature framework of the stress system will help to integrate stressrelated concepts from disparate fields of science and medicine, and allow the concept of stress to be common across different fields.

\section{THE BASIC FRAMEWORK OF THE STRESS SYSTEM}

Many scientists have noticed that the stress system contains several elements, such as stressful stimulus, stressor, and stress response $[4,5,9]$. Considering that the process of stress acting on the body is generally similar to other signal transduction processes, it should also include stimuli, receptors, and cascades. Therefore, we suggest the framework of the stress system should comprise five basic elements: stressful stimulus, stressor, stress, stress response, and stress effect (Figure 1A). In this framework, the stressful stimulus is the starting point, the effect is the end point, and stressor, stress, and stress response are cascades.

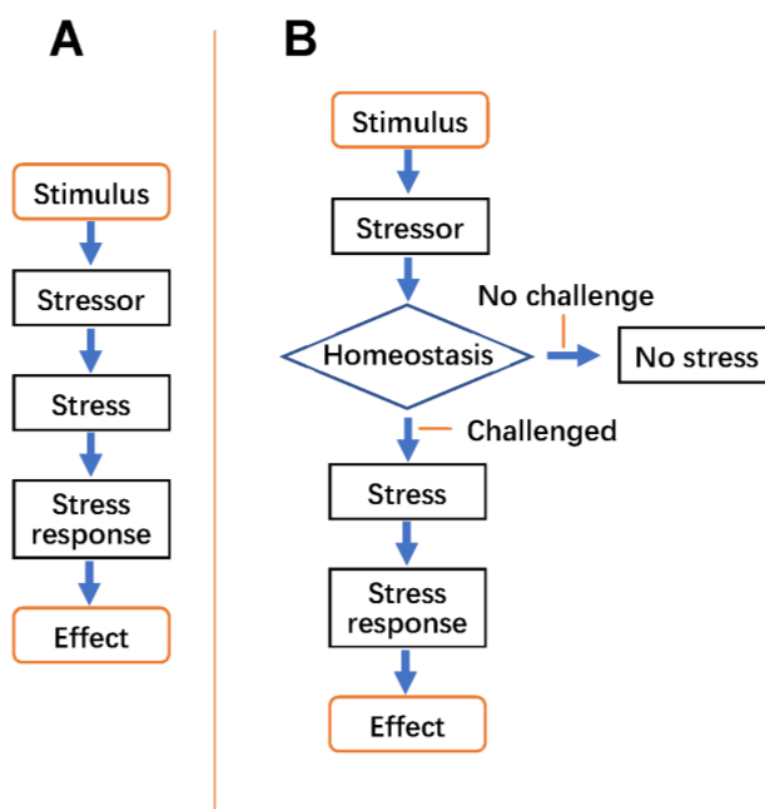

According to this framework, we may easily differentiate each element of the stress system. Taking oxidative stress as an example, reactive oxygen species (ROS) are stressors, the factors that stimulate the generation of ROS are stressful stimuli, a disruption of redox signaling and control caused by ROS is oxidative stress, the response that the body attempts to restore redox homeostasis is an oxidative stress response, and the resulting biological consequence is the effect of this stress.

Although the concept of stress is still confusing and controversial in many scientific pieces of literature, this framework may help readers to know the real meaning of stress in literatures. For instance, Selye defined "GAS" [3] is, in fact, both stress response and stress effect: the activation of the HPA axis is a systematic stress response, while physical and mental disorders produced by prolonged stress are stress effects. All treatments he used including heat, cold, and other noxious agents, are stressful stimuli. Since this paper has not revealed whether these stimuli are directly transferred into specific stressors, or induce the generation of specific stressors, it cannot be defined in which stress they have originally resulted in. But as Selye noticed, all these treatments caused a similar HPA activation-related stress response. To explain this phenomenon, Selye suggests that the stress is nonspecific and shared response, regardless of the nature of causative agents, or stressors [3, 9]. Later, this view of nonspecific stress response has been widely challenged $[4,10,11]$. This nonspecific stress response is not universal, especially it does not exist in isolated cells and tissues $[4,10]$. However, as the HPA axis is an "alarm system" for higher animals, in a

Framework evolution

FIGURE 1: The evolution of the framework of the stress system. (A) The basic framework of the stress system. (B) The developing framework of the stress system. (C) The mature framework of the stress system. 
sense, all stresses, once their intensity exceeds a certain threshold, may potentially cause HPA axis-related systematic stress response $[5,12]$.

\section{THE CONCEPTS OF STRESS}

Notably, the above basic framework of the stress system still has no "sensor", thus it is difficult to determine which stressors may result in stress and which may not. Fortunately, in the 1920s, Cannon coined "homeostasis [13]" referring to the tendency of a system to maintain the stability of milieu interieur [1], and found a wide variety of threats to homeostasis causing a similar sympathoadrenal response that he termed "fight-or-flight" response [14, 15], which we now know is a typical stress response. Therefore, homeostasis might be the candidate "sensor" of the stress system. Cannon defined stress as threats to homeostasis [2]. Selye also found the activation of HPA axis was a common response to diverse nocuous agents or sublethal doses of intoxications, and defined stress as the "nonspecific response of the body to any demand upon it" $[3,16,17]$.

Obviously, according to the above framework, stress defined by Cannon is stressor, and Selye's stress and Cannon's "fight-or-flight" response are stress responses. How- ever, through introducing homeostasis into the concept of stress, their works promote the evolution of the stress system, as homeostasis endows the framework of the stress system with the ability to sense stressors and judge whether they are threats or not (Figure 1B). With the help of homeostasis, it is easy to understand that not all stressors inevitably cause stress, but the stressors that threaten homeostasis do [5].

It is now clear that stress should be a state rather than a stressor or response [5], which has also been mentioned by Selye [9]. Based on homeostasis, all elements of the stress system can be clearly defined (BOX 1). Stressors are factors with the potential to directly challenge homeostasis. Stress is a state of homeostasis being challenged. Stressful stimuli are agents that can induce the formation of stressors or transfer to stressors. Stress response is a compensatory process aimed to restore homeostasis. Stress effects are biological consequences resulting from the struggle with stressors, which may include re-establishing homeostasis that promotes health (positive effects), or causing damage to the body or even diseases (negative effects).

\section{BOX 1 | Stress-related concepts.}

Stress: a state of homeostasis being challenged.

Stressor: factors with the potential to directly challenge homeostasis.

Stressful stimulus: agent that can induce the formation of stressors or transfer to stressor.

Stress response: a compensatory process aimed to restore homeostasis.

Stress effect: the biological consequence resulting from the struggle with a stressor, including the re-establishment of homeostasis, or the damage to the body and even diseases.

Eustress: a type of stress representing good stress. It is a state of homeostasis being mildly challenged by moderate levels of stressors (for instance, the levels of stressors within the "hermetic zone"), which can induce a mild stress response, enhance the buffering capacity of homeostasis, and benefit health.

Distress: a type of stress representing bad stress. It is a state of homeostasis being strongly challenged by high levels of stressors, which might induce a severe stress response, impair homeostasis, and endanger health.

Sustress: a type of stress representing inadequate stress. It is a state of homeostasis not challenged owing to no or inadequate stressors, which might shrink the buffering capacity of homeostasis and threaten health.

Stress system: a system that comprises stressful stimulus, stressor, stress, stress response, and stress effect.

Local stress: a type of stress occurring only at the place where stressors originated from (for instance, the stress induced by the accumulation of unfolded proteins in the endoplasmic reticulum is defined as endoplasmic reticulum stress).

System stress: a type of stress occurring systematically in the whole body independently of where stressors originated from (for instance, emotional change inducing the activation of the HPA axis is emotional stress).

Hormesis: a biphasic dose-depended adaptive response to stressors, that is, while high-level exposures to stressors could be detrimental for physiological functions, low-level exposures would be beneficial.

Homeostasis: a complex dynamic equilibrium, that is, 'maintenance of dynamic stability of milieu intérieur through constancy'.

Allostasis: a complex dynamic equilibrium, that is, 'maintenance of dynamic stability of milieu intérieur through being variable'. 
TABLE 1. Summary of stress responsive system.

\begin{tabular}{|c|c|c|c|c|c|}
\hline Organisms & Stresses & Stress-responsive system & Functions/Effects & $\begin{array}{l}\text { Typic stress or } \\
\text { syndrome }\end{array}$ & Refs \\
\hline Fungi & $\begin{array}{l}\text { Environmental } \\
\text { stress }\end{array}$ & Antioxidant defense system & $\begin{array}{l}\text { Adaptation, growth inhibi- } \\
\text { tion, et al. }\end{array}$ & $\begin{array}{l}\text { Oxidative } \\
\text { stress }\end{array}$ & [47] \\
\hline Plants & Abiotic stress & $\begin{array}{l}\text { Transcription factors, antiox- } \\
\text { idant defense system, et al. }\end{array}$ & $\begin{array}{l}\text { Adaptation, cell death, } \\
\text { oxidative damage, et al. }\end{array}$ & Heat stress & {$[33,67,68]$} \\
\hline \multirow{2}{*}{ Animals } & $\begin{array}{l}\text { Physiological } \\
\text { stress }\end{array}$ & $\begin{array}{l}\text { Hormones, transcription } \\
\text { factors, antioxidant defense } \\
\text { system, et al. }\end{array}$ & $\begin{array}{l}\text { Hormesis, structural dam- } \\
\text { age, functional loss, et al. }\end{array}$ & ER stress & [69-71] \\
\hline & $\begin{array}{l}\text { Psychological } \\
\text { stress }\end{array}$ & Hormones, HPA axis, et al. & Depression, et al. & $\begin{array}{l}\text { Post-traumatic } \\
\text { stress disor- } \\
\text { ders }\end{array}$ & {$[72,73]$} \\
\hline
\end{tabular}

\section{EXTENSION AND SPECIFICITY OF THE CONCEPT OF STRESS}

Initially, the term homeostasis coined by Cannon was a purely physiological concept in animals. Later, the concept was extended to the field of psychology, and cumulating evidence suggested that the activation of the HPA axis was more sensitive to emotional activities than physiological ones (Table 1). Therefore, stress was categorized into physiological stress and psychological stress [10]. Subsequent studies revealed that although different psychological activities could commonly activate the HPA axis, the phenotypes and mechanisms of corresponding stress were different from each other. Therefore, psychological stress was further classified into four main types according to specific functions (Table 2), that is, emotional stress [18], cognitive stress [19], perceptual stress [20], and psychosocial stress [21], and each type was sometimes further classified according to specific psychological stressors or stimuli, such as social defeat stress $[21,22]$, post-traumatic stress [23$25]$, and pandemic stress [26, 27].

Unlike psychological stress, which is mainly system stress, physiological stress includes both system stress and local stress. Therefore, only the specificity of systematic physiological stress is similar to that of psychological stress, that is, termed by specific stimuli or stressors (Table 2), such as oxidative stress [28], nutrient stress [29], heat stress [30], thermal stress [31], shear stress [32], drought stress [33], osmotic stress [34], mechanical stress [35], genotoxic stress [36], and so on. However, the specificity of most local physiological stress is termed according to the sites where stressors are produced (Table 2). For instance, cardiac stress [37], dopamine neuron-specific stress [38], cytoskeletal stress [39], mitochondrial stress [40, 41], endoplasmic reticulum stress [8, 42], and telomere stress [43] are stresses taking place only in specific cellular or subcellular sites. Besides, some physiological stresses are also classified by functions (Table 2 ), such as metabolic stress [44], replication stress [45], and neurodegenerative stress [46].

Notably, the concept of stress was also used in filamentous fungi [47] and plants [48]. Although these stresses mainly belonged to physiological stress, they were specifically termed as environmental stress and abiotic stress (Table 2), respectively. The subtypes of both environmental stress and abiotic stress were classified mainly according to stimuli (Table 2).

Besides, owing to the implications of homeostasis have extended to social and environmental science, the concept of stress has also expanded to related fields. Therefore, some specific stress concepts in social and environmental science have also been coined by related scientists $[26,47$, $49,50]$.

\section{STRESS, HORMESIS, SUSTRESS, EUSTRESS, DISTRESS, HOMEOSTASIS AND ALLOSTASIS}

For many scientists, the word stress is still closely associated with Selye defined "GAS" [3], and it seems all stress responses are negative for health. But over the last 80 years, science has expanded the concept of stress along many dimensions. Particularly, accumulating evidence illustrates that most stressors display a biphasic dosedependent effect on health, that is, while high-level exposures to stressors could be detrimental to health, low-level exposures would be beneficial [51]. These biphasic dose responses have been defined as "hormesis" (BOX 1) [52], and the low dose adaptive response is considered to be the result of compensatory biological processes to restore homeostasis perturbed by stressors [52]. A typical example is ROS-induced oxidative stress [53-56]. ROS are reactive molecules with the potential to damage proteins, lipids, nucleic acids, and other biomolecules [55]. Early studies suggested that ROS contributed to the pathogenesis of many diseases, and even promoted the aging process [57]. However, it is now clear that although excessive ROS may cause damage to biomolecules, maintenance of an optimal level of ROS is essential for modulating life processes [28, $55,58,59]$. Therefore, more and more researchers have come to realize that an optimal stress level is crucial for health, while an excessive or inadequate stress level might impair development, growth, and body composition, and lead to pathological conditions [5]. In this context, stress has to be divided into eustress, distress, and sustress (Fig- 
TABLE 2. The summary of stress types.

\begin{tabular}{|c|c|c|c|c|c|c|}
\hline \multirow{2}{*}{ Organisms } & \multicolumn{3}{|c|}{ Stresses } & \multicolumn{2}{|r|}{ Stimuli } & \multirow{2}{*}{ Refs } \\
\hline & Types & Subtype Basis & Subtype examples & Type & Examples & \\
\hline \multirow{6}{*}{ Fungi } & \multicolumn{5}{|c|}{ Environmental stress } & {$[47]$} \\
\hline & \multirow{5}{*}{\multicolumn{2}{|c|}{ Stimuli }} & Oxidative stress & \multirow{5}{*}{ Chemical } & $\begin{array}{l}\mathrm{H}_{2} \mathrm{O}_{2} \\
\text { Menadione Sodium bisul- } \\
\text { phite }\end{array}$ & \\
\hline & & & Osmotic stress & & $\begin{array}{l}\mathrm{NaCl} \\
\text { Sorbitol }\end{array}$ & \\
\hline & & & CWI stress & & Congo Red & \\
\hline & & & Heavy metal stress & & $\mathrm{CdCl}_{2}$ & \\
\hline & & & et al. & & et al. & \\
\hline \multirow{4}{*}{ Plants } & \multicolumn{5}{|c|}{ Abiotic stress } & \\
\hline & \multirow{3}{*}{\multicolumn{2}{|c|}{ Stimuli }} & $\begin{array}{l}\text { Drought stress } \\
\text { Heat stress } \\
\text { Salt stress } \\
\text { et al. }\end{array}$ & Physical & $\begin{array}{l}\text { Drought } \\
\text { Temperature } \\
\text { Salt } \\
\text { et al. }\end{array}$ & $\begin{array}{l}{[74-76]} \\
{[67,77]} \\
{[75]}\end{array}$ \\
\hline & & & \multirow{2}{*}{$\begin{array}{l}\text { Oxidative stress } \\
\text { et al. }\end{array}$} & \multirow[t]{2}{*}{ Chemical } & $\begin{array}{l}\text { ROS } \\
\text { Toxic chemicals }\end{array}$ & $\begin{array}{l}{[48,68,} \\
78] \\
{[79]}\end{array}$ \\
\hline & & & & & et al. & \\
\hline \multirow{16}{*}{ Animals } & \multicolumn{5}{|c|}{ Physiological stress } & \\
\hline & \multirow{4}{*}{\multicolumn{2}{|c|}{ Stimuli }} & $\begin{array}{l}\text { Cold stress } \\
\text { Heat stress } \\
\text { Radiation stress } \\
\text { Noise stress } \\
\text { Vibration stress } \\
\text { et al. }\end{array}$ & Physical & $\begin{array}{l}\text { Cold } \\
\text { Heat } \\
\text { Radiation } \\
\text { Noise } \\
\text { Vibration } \\
\text { et al. }\end{array}$ & $\begin{array}{l}{[80,81]} \\
{[82,83]} \\
{[84]} \\
{[85,86]} \\
{[87]}\end{array}$ \\
\hline & & & $\begin{array}{l}\text { Chemical stress } \\
\text { et al. }\end{array}$ & Chemical & Chemicals & {$[88]$} \\
\hline & & & Chemical stress & \multirow{2}{*}{ Biological } & Metabolites & [89] \\
\hline & & & et al. & & et al & \\
\hline & \multirow{4}{*}{\multicolumn{2}{|c|}{ Functions }} & Metabolic stress & & & [44] \\
\hline & & & Replication stress & & & {$[45]$} \\
\hline & & & $\begin{array}{l}\text { Neurodegenerative } \\
\text { stress }\end{array}$ & & & [46] \\
\hline & & & et al. & & & \\
\hline & \multirow{7}{*}{\multicolumn{2}{|c|}{ Locations }} & Cardiac stress & & & [37] \\
\hline & & & $\begin{array}{l}\text { Dopamine neuron- } \\
\text { specific stress }\end{array}$ & & & [38] \\
\hline & & & Cytoskeletal stress & & & [39] \\
\hline & & & Mitochondrial stress & & & {$[40,41]$} \\
\hline & & & $\begin{array}{l}\text { Endoplasmic reticulum } \\
\text { stress }\end{array}$ & & & {$[8,42]$} \\
\hline & & & Telomere stress & & & {$[43]$} \\
\hline & & & et al. & & & \\
\hline
\end{tabular}


TABLE 2 (continued). The summary of stress types.

\begin{tabular}{|c|c|c|c|c|c|c|}
\hline \multirow{2}{*}{ Organisms } & \multicolumn{3}{|c|}{ Stresses } & \multicolumn{2}{|r|}{ Stimuli } & \multirow{2}{*}{ Refs } \\
\hline & Types & Subtype Basis & Subtype examples & Type & Examples & \\
\hline \multirow{5}{*}{ Animals } & Psycho & ogical stress & & & & \\
\hline & \multirow{4}{*}{\multicolumn{2}{|c|}{ Functions }} & Emotional Stress & Emotional & $\begin{array}{l}\text { Anxiety } \\
\text { Fear } \\
\text { Grief } \\
\text { Anger } \\
\text { et al. }\end{array}$ & $\begin{array}{l}{[90]} \\
{[91,92]} \\
{[92]} \\
{[92]}\end{array}$ \\
\hline & & & Cognitive stress & Cognitive & $\begin{array}{l}\text { Pandemic } \\
\text { Information overload } \\
\text { Disruptions } \\
\text { Interruptions } \\
\text { Aging } \\
\text { et al. }\end{array}$ & $\begin{array}{l}27] \\
{[93]} \\
{[93]} \\
{[93]} \\
{[19]}\end{array}$ \\
\hline & & & Perceptual stress & Perceptual & $\begin{array}{l}\text { Aging } \\
\text { Addiction } \\
\text { Competition } \\
\text { et al. }\end{array}$ & $\begin{array}{l}{[94,95]} \\
{[96]} \\
{[97]}\end{array}$ \\
\hline & & & Psychosocial stress & Psychosocial & $\begin{array}{l}\text { Social defeat } \\
\text { Social confrontations } \\
\text { Racial disparity } \\
\text { Trauma from life events } \\
\text { et al. }\end{array}$ & $\begin{array}{l}{[21,22]} \\
{[22]} \\
{[98]} \\
{[25]}\end{array}$ \\
\hline
\end{tabular}

ure 1C, BOX 1). Here, eustress means good stress, that is, homeostasis has been mildly challenged by moderate levels of stressors (for instance, the levels of stressors within the "hermetic zone" [60]). Eustress might induce a mild stress response, enhance the buffering capacity of homeostasis [61], and benefit health. Distress means bad stress, that is, homeostasis has been strongly challenged by high levels of stressors, which might induce a severe stress response, impair homeostasis, and endanger health. Sustress is coined from the Latin 'sus' (an assimilated form of the Latin "sub-" before "-s-") meaning 'less than normal' and 'stress' to mean 'no or inadequate stress'. Sustress might shrink the buffering capacity of homeostasis [61] and threaten health $[5,58]$. The above "GAS" [3] only represents the responses and effects resulting from distress, but not eustress and sustress.

In this framework of the stress system (Figure 1C), homeostasis likes a 'commander', which senses different stressors and directs subsequent stress responses and effects. Notably, although the concept of homeostasis has still been widely used, its original meaning of 'maintenance of dynamic stability of milieu intérieur through constancy' (Figure 2) has been challenged, because the baseline of homeostasis might be dynamic rather than constant. Accumulating evidence indicates that many physiological indexes and activities including blood pressure, body temperature, the secretion of hormones, and the expression of proteins and genes, display a typical circadian rhythm. Therefore, in 1988, Sterling and Eyer coined a new term 'allostasis' (BOX 1) from the Greek 'allo' meaning 'variable', and 'stasis' meaning 'stable', to represent "remaining stable by being variable' [62]. As illustrated in Figure 2, the only difference between these two concepts is that the baseline of allostasis is variable, while that of homeostasis is constant. Most of the dynamic equilibrium of milieu intérieur should be allostasis rather than homeostasis. In this context, McEwen coined the term "allostatic load" to describe the stress process $[63,64]$.

\section{SUMMARY AND PERSPECTIVES}

Stress is a state of homeostasis being challenged. Along with the concept of homeostasis extending to the fields of physiology, psychology, and even environmental science, the concept of stress has evolved dramatically. It is now clear that stress might take place systematically through activating the HPA axis (system stress) or take place only at the site where stressors are induced or generated (local stress). Since any stressor may be sensed by existing homeostasis and potentially trigger responses at molecular, cellular, and systemic levels to preserve the homeostasis and induce adaptation, the concept of stress has been specified according to different stressful stimuli, stressors, sites, or functions, such as emotional stress, oxidative stress, mitochondrial stress, metabolic stress, and so on. As research continues, many more specific stresses will emerge.

Stress functions through the stress system, and it contains three basic types: distress, eustress, and sustress. 


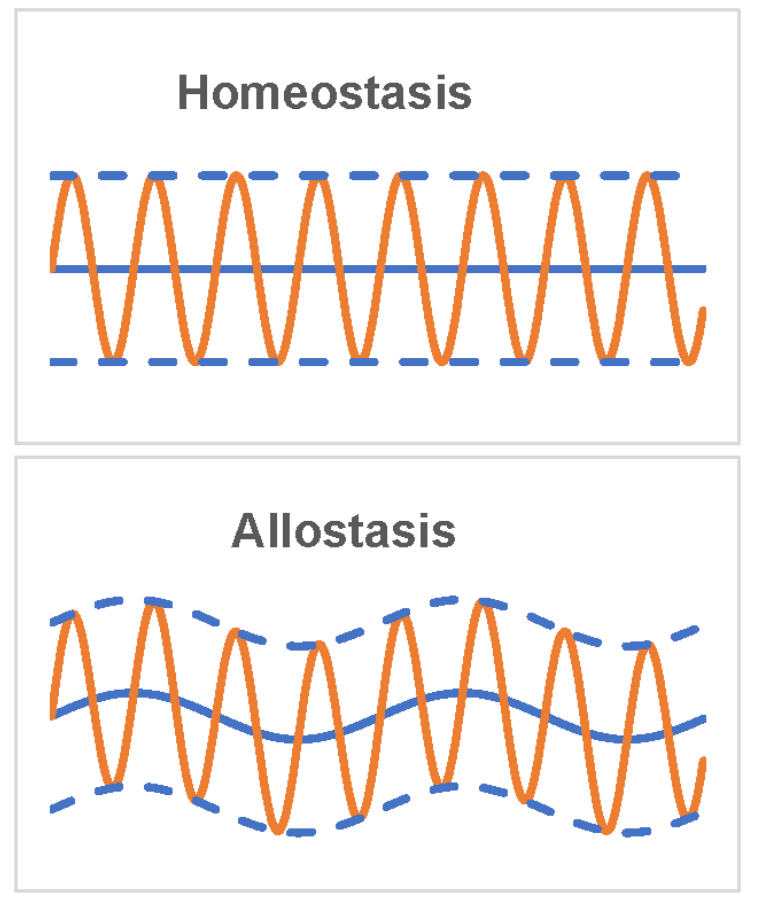

FIGURE 2: Homeostasis and allostasis. Blue solid line represents the baseline, orange line represents dynamic equilibrium, and blue dot line represents the boundary of dynamic equilibrium.

While distress may impair normal physiological function, eustress plays a critical role in the adaptive process of assessing and disposing of stressors, and endowing the individual to prepare for and survive future challenges [65], and sustress may weaken the basal activity and responsiveness of the stress system [5]. Therefore, more and more researchers have come to realize that an optimal stress level is essential for building biological shields through hormesis to guarantee normal life processes [5, 66].

The word of stress has permeated our culture in many dimensions, while the stress concept is still confusing and

\section{REFERENCES}

1. Holmes FL (1986). Claude Bernard, the milieu interieur, and regulatory physiology. Hist Philos Life Sci 8(1): 3-25. PMID: 3534926

2. Cannon WB (1935). Stresses and strains of homeostasis. Am J Med Sci 189(1): 13-14. doi: 10.1097/00000441-193501000-00001

3. Selye H (1936). A syndrome produced by diverse nocuous agents. Nature 138(3479): 32-32. doi: 10.1038/138032a0

4. Goldstein DS, Kopin IJ (2007). Evolution of concepts of stress. Stress 10(2): 109-120. doi: 10.1080/10253890701288935

5. Chrousos GP (2009). Stress and disorders of the stress system. Nat Rev Endocrinol 5(7): 374-381. doi: 10.1038/nrendo.2009.106

6. Sies $\mathrm{H}$ (2015). Oxidative stress: a concept in redox biology and medicine. Redox Biol 4; 180-183. doi: 10.1016/j.redox.2015.01.002

7. Jones DP (2006). Redefining oxidative stress. Antioxid Redox Signal 8(9-10): 1865-1879. doi: 10.1089/ars.2006.8.1865 controversial. We hope this framework of the stress system will help distinguish the true meaning of the stress concept appearing in different pieces of literature, integrate stress-related concepts from disparate fields of science and medicine, and allow the concept of stress to be common across different fields.

\section{AUTHOR CONTRIBUTIONS}

G.L. and S.L. wrote the manuscript, and F.W. and G.L. revised the manuscript.

\section{ACKNOWLEDGMENTS}

G.L. was supported by the National Natural Science Funds of China (31871198, 31741070), Cooperative Innovation Center of Engineering and New Products for Developmental Biology of Hunan Province (20134486), and the Opening Fund of The National \& Local Joint Engineering Laboratory of Animal Peptide Drug Development (Hunan Normal University), National Development and Reform Commission. F.W. was supported by the National Natural Science Funds of China (81903138), and the Natural Science Funds of Hunan Province (2019JJ50778). The funding sponsors had no role in the writing of the manuscript, and in the decision to submit the manuscript for publication.

\section{CONFLICT OF INTEREST}

The authors declare no competing financial interests.

\section{COPYRIGHT}

(C) $2021 \mathrm{Lu}$ et al. This is an open-access article released under the terms of the Creative Commons Attribution (CC BY) license, which allows the unrestricted use, distribution, and reproduction in any medium, provided the original author and source are acknowledged.

Please cite this article as: Siyu Lu, Fang Wei and Guolin Li (2021). The evolution of the concept of stress and the framework of the stress system. Cell Stress 5(6): 76-85. doi: 10.15698/cst2021.06.250

8. Walter $P$, Ron $D$ (2011). The unfolded protein response: From stress pathway to homeostatic regulation. Science 334(6059): 1081-1086. doi: 10.1126/SCIENCE.1209038

9. Selye H (1975). Confusion and controversy in the stress field. J Human Stress 1(2): 37-44. doi: 10.1080/0097840X.1975.9940406

10. Mason JW (1975). A historical view of the stress field. J Human Stress 1(2): 22-36 concl. doi: 10.1080/0097840X.1975.9940405

11. Nageishi Y (2015). A critical review of selye's stress theory: The statistical analyses of Selye's own experimental data disprove it. Psychology 06(14): 1786-1794. doi: 10.4236/psych.2015.614175

12. Chrousos GP, Gold PW (1992). The concepts of stress and stress system disorders. Overview of physical and behavioral homeostasis. JAMA 267(9): 1244-1252. doi: 10.1001/jama.1992.03480090092034 
13. Cannon WB (1929). Organization for physiological homeostasis Physiol Rev 9(3): 399-431. doi: 10.1152/physrev.1929.9.3.399

14. Cannon WB (1929). Bodily changes in pain, hunger, fear, and rage. D. Appleton \& Company, New York and London; pp 404

15. Cannon WB (1932). The wisdom of the body. W.W. Norton \& Company, Inc., New York.

16. Selye H (1956). The stress of life. McGraw-Hill, New York.

17. Selye H (1974). Stress without distress. Lippincott Williams \& Wilkins, Philadelphia.

18. Mu MD, Geng HY, Rong KL, Peng RC, Wang ST, Geng LT, Qian ZM, Yung $W H$, Ke $Y$ (2020). A limbic circuitry involved in emotional stressinduced grooming. Nat Commun 11(1): 2261. doi: 10.1038/s41467020-16203-x

19. Cole KR, Shields RK (2019). Age and cognitive stress influences motor skill acquisition, consolidation, and dual-task effect in humans. J Mot Behav 51(6): 622-639. doi: 10.1080/00222895.2018.1547893

20. McKone E, Brewer JL, MacPherson S, Rhodes G, Hayward WG (2007). Familiar other-race faces show normal holistic processing and are robust to perceptual stress. Perception 36(2): 224-248. doi: $10.1068 /$ p5499

21. Kataoka N, Shima Y, Nakajima K, Nakamura K (2020). A central master driver of psychosocial stress responses in the rat. Science 367(6482): 1105-1112. doi: 10.1126/science.aaz4639

22. Lowry CA, Jin AY (2020). Improving the social relevance of experimental stroke models: Social isolation, social defeat stress and stroke outcome in animals and humans. Front Neurol 11: 427. doi: 10.3389/fneur.2020.00427

23. Miller JV, Andre Q, Timmers I, Simons L, Rasic N, Lebel C, Noel M (2021). Subclinical post-traumatic stress symptomology and brain structure in youth with chronic headaches. Neuroimage Clin 30: 102627. doi: 10.1016/j.nicl.2021.102627

24. Kronish IM, Cornelius T, Schwartz JE, Shechter A, Diaz KM, Romero EK, Edmondson D (2020). Posttraumatic stress disorder and electronically measured medication adherence after suspected acute coronary syndromes. Circulation 142(8): 817-819. doi: 10.1161/circulationaha.120.045714

25. O'Neil A, Scovelle AJ, Milner AJ, Kavanagh A (2018). Gender/sex as a social determinant of cardiovascular risk. Circulation 137(8): 854864. doi: 10.1161/CIRCULATIONAHA.117.028595

26. Salisbury H (2020). Helen salisbury: Pandemic stress. BMJ 371 m4276. doi: 10.1136/bmj.m4276

27. Lohmus M, Stenfors CUD, Lind T, Lauber A, Georgelis A (2021). Mental health, greenness, and nature related behaviors in the adult population of stockholm county during COVID-19-related restrictions. Int J Environ Res Public Health 18(6): 3303. doi: 10.3390/ijerph18063303

28. Sies H, Berndt C, Jones DP (2017). Oxidative Stress. Annu Rev Biochem 86: 715-748. doi: 10.1146/annurev-biochem-061516-045037

29. An H, Ordureau A, Körner M, Paulo JA, Harper JW (2020). Systematic quantitative analysis of ribosome inventory during nutrient stress. Nature 583(7815): 303-309. doi: 10.1038/s41586-020-2446-y

30. Luo M, Meng Z, Moroishi T, Lin KC, Shen G, Mo F, Shao B, Wei X, Zhang $P$, Wei $Y$, Guan KL (2020). Heat stress activates YAP/TAZ to induce the heat shock transcriptome. Nat Cell Biol 22(12): 1447-1459. doi: 10.1038/s41556-020-00602-9

31. Belfield EJ, Brown C, Ding ZJ, Chapman L, Luo M, Hinde E, van Es SW, Johnson S, Ning Y, Zheng SJ, Mithani A, Harberd NP (2020). Ther- mal stress accelerates Arabidopsis thaliana mutation rate. Genome Res doi: 10.1101/gr.259853.119

32. Yamamoto K, Nogimori $Y$, Imamura H, Ando J (2020). Shear stress activates mitochondrial oxidative phosphorylation by reducing plasma membrane cholesterol in vascular endothelial cells. Proc Natl Acad Sci U S A 117(52): 33660-33667. doi: 10.1073/pnas.2014029117

33. Dong Z, Xu Z, Xu L, Galli M, Gallavotti A, Dooner HK, Chuck G (2020). Necrotic upper tips1 mimics heat and drought stress and encodes a protoxylem-specific transcription factor in maize. Proc Nat Acad Sci U S A 117(34): 20908-20919. doi: 10.1073/pnas.2005014117

34. Peran I, Sabri N, Mittag T (2020). Managing hyperosmotic stress through phase separation. Trends Biochem Sci 45(9): 721-723. doi: 10.1016/j.tibs.2020.05.004

35. Nava MM, Miroshnikova YA, Biggs LC, Whitefield DB, Metge $F$, Boucas J, Vihinen H, Jokitalo E, Li X, García Arcos JM, Hoffmann B, Merkel R, Niessen CM, Dahl KN, Wickström SA (2020). Heterochromatin-driven nuclear softening protects the genome against mechanical stress-induced damage. Cell 181(4): 800-817.e822. doi: 10.1016/j.cell.2020.03.052

36. Berti M, Cortez D, Lopes M (2020). The plasticity of DNA replication forks in response to clinically relevant genotoxic stress. Nat Rev Mol Cell Biol 21(10): 633-651. doi: 10.1038/s41580-020-0257-5

37. Valente AM, Bhatt DL, Lane-Cordova A (2020). Pregnancy as a cardiac stress test: Time to include obstetric history in cardiac risk assessment? J Am Coll Cardiol 76(1): 68-71. doi: 10.1016/j.jacc.2020.05.017

38. Fernandes HJR, Patikas N, Foskolou S, Field SF, Park JE, Byrne ML Bassett AR, Metzakopian E (2020). Single-cell transcriptomics of Parkinson's disease human in vitro models reveals dopamine neuronspecific stress responses. Cell Rep 33(2): 108263. doi 10.1016/j.celrep.2020.108263

39. Doss BL, Pan M, Gupta M, Grenci G, Mège RM, Lim CT, Sheetz MP Voituriez R, Ladoux B (2020). Cell response to substrate rigidity is regulated by active and passive cytoskeletal stress. Proc Natl Acad Sci U S A 117(23): 12817-12825. doi: 10.1073/pnas.1917555117

40. Clyde D (2020). Spaceflight causes mitochondrial stress. Nat Rev Genet 22(2): 69. doi: 10.1038/s41576-020-00322-8.

41. da Silveira WA, Fazelinia $H$, Rosenthal SB, Laiakis EC, Kim MS, Meydan C, Kidane Y, Rathi KS, Smith SM, Stear B, Ying Y, Zhang Y, Foox J, Zanello S, Crucian B, Wang D, Nugent A, Costa HA, Zwart SR, Schrepfer S, Elworth RAL, Sapoval N, Treangen T, Mackay M, Gokhale NS, Horner SM, Singh LN, Wallace DC, Willey JS, Schisler JC, et al. (2020). Comprehensive multi-omics analysis reveals mitochondrial stress as a central biological hub for spaceflight impact. Cell 183(5): 11851201.e1120. doi: 10.1016/j.cell.2020.11.002

42. Chen X, Cubillos-Ruiz JR (2020). Endoplasmic reticulum stress signals in the tumour and its microenvironment. Nat Rev Cancer 21(2): 71-88. doi: 10.1038/s41568-020-00312-2

43. Mender I, Zhang A, Ren Z, Han C, Deng Y, Siteni S, Li H, Zhu J, Vemula A, Shay JW, Fu YX (2020). Telomere stress potentiates stingdependent anti-tumor Immunity. Cancer Cell 38(3): 400-411.e406. doi: 10.1016/j.ccell.2020.05.020

44. Lamper AM, Fleming RH, Ladd KM, Lee ASY (2020). A phosphorylation-regulated elF3d translation switch mediates cellular adaptation to metabolic stress. Science 370(6518): 853-856. doi: 10.1126/science.abb0993

45. Lamm N, Read MN, Nobis M, Van Ly D, Page SG, Masamsetti VP, Timpson P, Biro M, Cesare AJ (2020). Nuclear F-actin counteracts nuclear deformation and promotes fork repair during replication stress. Nat Cell Biol 22(12): 1460-1470. doi: 10.1038/s41556-020 00605-6 
46. Cooper ML, Pasini S, Lambert WS, D'Alessandro KB, Yao V, Risner $\mathrm{ML}$, Calkins DJ (2020). Redistribution of metabolic resources through astrocyte networks mitigates neurodegenerative stress. Proc Nat Acad Sci U S A 117(31): 18810-18821. doi: 10.1073/pnas.2009425117

47. Orosz E, van de Wiele N, Emri T, Zhou M, Robert V, de Vries RP Pocsi I (2018). Fungal Stress Database (FSD)--a repository of fungal stress physiological data. Database 2018: bay009. doi: 10.1093/database/bay009

48. Zandalinas SI, Fichman Y, Devireddy AR, Sengupta S, Azad RK, Mittler R (2020). Systemic signaling during abiotic stress combination in plants. Proc Natl Acad Sci U S A 117(24): 13810-13820. doi: 10.1073/pnas.2005077117

49. Zou WJ, Song YL, Wu MY, Chen XT, You QL, Yang Q, Luo ZY, Huang L, Kong Y, Feng J, Fang DX, Li XW, Yang JM, Mei L, Gao TM (2020). A discrete serotonergic circuit regulates vulnerability to social stress. Nat Commun 11(1): 4218. doi: 10.1038/s41467-020-18010-w

50. Zhang R, Tielbörger K (2020). Density-dependence tips the change of plant-plant interactions under environmental stress. Nat Commun 11(1): 2532. doi: 10.1038/s41467-020-16286-6

51. Calabrese EJ, Mattson MP (2017). How does hormesis impact biology, toxicology, and medicine? NPJ Aging Mech Dis 3(1): 13. doi: 10.1038/s41514-017-0013-z

52. Calabrese EJ, Baldwin LA (2002). Defining hormesis. Hum Exp Toxicol 21(2): 91-97. doi: 10.1191/0960327102ht217oa

53. Aschbacher K, O'Donovan A, Wolkowitz OM, Dhabhar FS, Su Y, Epel E (2013). Good stress, bad stress and oxidative stress: insights from anticipatory cortisol reactivity. Psychoneuroendocrinology 38(9): 1698-1708. doi: 10.1016/j.psyneuen.2013.02.004

54. Siegrist J, Sies H (2017). Disturbed redox homeostasis in oxidative distress: A molecular link from chronic psychosocial work stress to coronary heart disease? Circ Res 121(2): 103-105. doi: 10.1161/CIRCRESAHA.117.311182

55. Sies $\mathrm{H}$, Jones DP (2020). Reactive oxygen species (ROS) as pleiotropic physiological signalling agents. Nat Rev Mol Cell Biol 21(7): 363-383. doi: 10.1038/s41580-020-0230-3

56. Sies H (2021). Oxidative eustress: On constant alert for redox homeostasis. Redox Biol 41: 101867. doi: 10.1016/j.redox.2021.101867

57. Beckman KB, Ames BN (1998). The free radical theory of aging matures. Physiol Rev 78(2): 547-581. doi: 10.1152/physrev.1998.78.2.547

58. Finkel T, Holbrook NJ (2000). Oxidants, oxidative stress and the biology of ageing. Nature 408(6809): 239-247. doi: 10.1038/35041687

59. Sies H (2017). Hydrogen peroxide as a central redox signaling molecule in physiological oxidative stress: Oxidative eustress. Redox Biol 11; 613-619. doi: 10.1016/j.redox.2016.12.035

60. Calabrese EJ, Baldwin LA (1998). Hormesis as a biological hypothesis. Environ Health Perspect 106 (Suppl 1): 357-362. doi: 10.1289/ehp.106-1533487

61. Li G, He H (2009). Hormesis, allostatic buffering capacity and physiological mechanism of physical activity: A new theoretic framework. Med Hypotheses 72(5): 527-532. doi: 10.1016/j.mehy.2008.12.037

62. Sterling P, Eyer J (1988). Allostasis: A new paradigm to explain arousal pathology. Handbook of life stress, cognition and health. John Wiley \& Sons, Oxford, England; pp 629-649.

63. McEwen BS (2003). Interacting mediators of allostasis and allostatic load: towards an understanding of resilience in aging. Metabolism 52(10 Suppl 2): 10-16. doi: 10.1016/s0026-0495(03)00295-6
64. McEwen BS (2007). Physiology and neurobiology of stress and adaptation: central role of the brain. Physiol Rev 87(3): 873-904. doi: 10.1152/physrev.00041.2006

65. McEwen BS, Akil H (2020). Revisiting the stress concept: Implications for affective Disorders. J Neurosci 40(1): 12-21. doi 10.1523/jneurosci.0733-19.2019

66. Calabrese EJ, Agathokleous E (2019). Building biological shields via hormesis. Trends Pharmacol Sci 40(1): 8-10. doi: 10.1016/j.tips.2018.10.010

67. Zhu J, Verslues PE, Zheng X, Lee BH, Zhan X, Manabe Y, Sokolchik I, Zhu Y, Dong CH, Zhu JK, Hasegawa PM, Bressan RA (2005). HOS10 encodes an R2R3-type MYB transcription factor essential for cold acclimation in plants. Proc Natl Acad Sci U S A 102(28): 9966-9971. doi: 10.1073/pnas.0503960102

68. Foyer $\mathrm{CH}$, Noctor $\mathrm{G}$ (2020). Redox Homeostasis and Signaling in a Higher-CO2 World. Annu Rev Plant Biol 71: 157-182. doi: 10.1146/annurev-arplant-050718-095955

69. Nacher J, Varea E, Blasco-Ibanez JM, Castillo-Gomez E, Crespo C, Martinez-Guijarro FJ, McEwen BS (2005). Expression of the transcription factor Pax 6 in the adult rat dentate gyrus. J Neurosci Res 81(6): 753-761. doi: 10.1002/jnr.20596

70. Stengel ST, Fazio A, Lipinski S, Jahn MT, Aden K, Ito G, Wottawa F, Kuiper JWP, Coleman OI, Tran F, Bordoni D, Bernardes JP, Jentzsch M, Luzius A, Bierwirth S, Messner B, Henning A, Welz L, Kakavand N, FalkPaulsen $M$, Imm S, Hinrichsen F, Zilbauer M, Schreiber S, Kaser A, Blumberg R, Haller D, Rosenstiel P (2020). Activating transcription factor 6 mediates inflammatory signals in intestinal epithelial cells upon endoplasmic reticulum stress. Gastroenterology 159(4): 1357 1374.e1310. doi: 10.1053/j.gastro.2020.06.088

71. Fink G (2007). Encyclopedia of stress. Academic Press, Amster dam.

72. Regel S, Joseph S (2017). Post-traumatic stress. Oxford University Press, Oxford.

73. Kloet ERd, Oitzl MS, Vermetten E (2007). Stress hormones and post traumatic stress disorder : basic studies and clinical perspectives. Elsevier, Amsterdam, Boston

74. Salehin M, Li B, Tang M, Katz E, Song L, Ecker JR, Kliebenstein DJ Estelle M (2019). Auxin-sensitive Aux/IAA proteins mediate drought tolerance in Arabidopsis by regulating glucosinolate levels. Nat Commun 10(1): 4021. doi: 10.1038/s41467-019-12002-1

75. Ha CV, Leyva-Gonzalez MA, Osakabe Y, Tran UT, Nishiyama R, Watanabe Y, Tanaka M, Seki M, Yamaguchi S, Dong NV, YamaguchiShinozaki K, Shinozaki K, Herrera-Estrella L, Tran LS (2014). Positive regulatory role of strigolactone in plant responses to drought and salt stress. Proc Natl Acad Sci U S A 111(2): 851-856. doi: 10.1073/pnas.1322135111

76. Tran LS, Urao T, Qin F, Maruyama K, Kakimoto T, Shinozaki K, Yamaguchi-Shinozaki $K$ (2007). Functional analysis of AHK1/ATHK1 and cytokinin receptor histidine kinases in response to abscisic acid, drought, and salt stress in Arabidopsis. Proc Natl Acad Sci U S A 104(51): 20623-20628. doi: 10.1073/pnas.0706547105

77. Meng X, Liang Z, Dai X, Zhang Y, Mahboub S, Ngu DW, Roston RL, Schnable JC (2021). Predicting transcriptional responses to cold stress across plant species. Proc Natl Acad Sci U S A 118(10). doi: 10.1073/pnas.2026330118

78. Apel K, Hirt H (2004). Reactive oxygen species: metabolism, oxidative stress, and signal transduction. Annu Rev Plant Biol 55: 373-399. doi: 10.1146/annurev.arplant.55.031903.141701

79. Melo JO, Martins LGC, Barros BA, Pimenta MR, Lana UGP, Duarte CEM, Pastina MM, Guimaraes CT, Schaffert RE, Kochian LV, Fontes 
EPB, Magalhaes JV (2019). Repeat variants for the SbMATE transporter protect sorghum roots from aluminum toxicity by transcriptional interplay in cis and trans. Proc Natl Acad Sci U S A 116(1): 313318. doi: $10.1073 /$ pnas. 1808400115

80. Latorre-Muro $P, O^{\prime}$ Malley KE, Bennett CF, Perry EA, Balsa E, Tavares CDJ, Jedrychowski M, Gygi SP, Puigserver P (2021). A coldstress-inducible PERK/OGT axis controls TOM70-assisted mitochondrial protein import and cristae formation. Cell Metab 33(3): 598-614 e597. doi: 10.1016/j.cmet.2021.01.013

81. Raun SH, Henriquez-Olguin C, Karavaeva I, Ali M, Moller LLV, Kot W, Castro-Mejia JL, Nielsen DS, Gerhart-Hines Z, Richter EA, Sylow L (2020). Housing temperature influences exercise training adaptations in mice. Nat Commun 11(1): 1560. doi: 10.1038/s41467-020-15311-y

82. Periard JD, Eijsvogels TMH, Daanen HAM (2021). Exercise under heat stress: thermoregulation, hydration, performance implications and mitigation strategies. Physiol Rev. doi: 10.1152/physrev.00038.2020

83. Radecker N, Pogoreutz C, Gegner HM, Cardenas A, Roth F, Bougoure J, Guagliardo P, Wild C, Pernice M, Raina JB, Meibom A, Voolstra CR (2021). Heat stress destabilizes symbiotic nutrient cycling in corals. Proc Natl Acad Sci U S A 118(5): e2022653118. doi: 10.1073/pnas.2022653118

84. Scaramozza A, Park D, Kollu S, Beerman I, Sun X, Rossi DJ, Lin CP, Scadden DT, Crist C, Brack AS (2019). Lineage tracing reveals a subset of reserve muscle stem cells capable of clonal expansion under stress. Cell Stem Cell 24(6): 944-957 e945. doi: 10.1016/j.stem.2019.03.020

85. Han W, Shin JO, Ma JH, Min H, Jung J, Lee J, Kim UK, Choi JY, Moon SJ, Moon DW, Bok J, Kim CH (2020). Distinct roles of stereociliary links in the nonlinear sound processing and noise resistance of cochlear outer hair cells. Proc Natl Acad Sci U S A 117(20): 11109-11117. doi: 10.1073/pnas.1920229117

86. Munzel T, Daiber A, Steven S, Tran LP, Ullmann E, Kossmann S, Schmidt FP, Oelze M, Xia N, Li H, Pinto A, Wild P, Pies K, Schmidt ER, Rapp S, Kroller-Schon S (2017). Effects of noise on vascular function, oxidative stress, and inflammation: mechanistic insight from studies in mice. Eur Heart J 38(37): 2838-2849. doi: 10.1093/eurheartj/ehx081

87. Ries AS, Hermanns T, Poeck B, Strauss R (2017). Serotonin modulates a depression-like state in Drosophila responsive to lithium treatment. Nat Commun 8: 15738. doi: 10.1038/ncomms15738

88. Galluzzi L, Vitale I, Senovilla L, Olaussen KA, Pinna G, Eisenberg T, Goubar A, Martins I, Michels J, Kratassiouk G, Carmona-Gutierrez D, Scoazec M, Vacchelli E, Schlemmer F, Kepp O, Shen S, Tailler M, NisoSantano M, Morselli E, Criollo A, Adjemian S, Jemaa M, Chaba K, Pailleret C, Michaud M, Pietrocola F, Tajeddine N, de La Motte Rouge T, Araujo N, Morozova N, et al. (2012). Prognostic impact of vitamin B6 metabolism in lung cancer. Cell Rep 2(2): 257-269. doi: 10.1016/j.celrep.2012.06.017
89. Park BK, Boobis A, Clarke S, Goldring CE, Jones D, Kenna JG, Lambert C, Laverty HG, Naisbitt DJ, Nelson S, Nicoll-Griffith DA, Obach RS, Routledge $P$, Smith DA, Tweedie DJ, Vermeulen N, Williams DP, Wilson ID, Baillie TA (2011). Managing the challenge of chemically reactive metabolites in drug development. Nat Rev Drug Discov 10(4): 292 306. doi: $10.1038 / \mathrm{nrd} 3408$

90. Jabre $\mathrm{P}$, Belpomme V, Azoulay E, Jacob L, Bertrand L, Lapostolle $F$, Tazarourte K, Bouilleau G, Pinaud V, Broche C, Normand D, Baubet T, Ricard-Hibon A, Istria J, Beltramini A, Alheritiere A, Assez N, Nace L, Vivien B, Turi L, Launay S, Desmaizieres M, Borron SW, Vicaut E, Adnet F (2013). Family presence during cardiopulmonary resuscitation. N Engl J Med 368(11): 1008-1018. doi: 10.1056/NEJMoa1203366

91. Lui S, Huang $X$, Chen L, Tang $H$, Zhang $T$, Li X, Li D, Kuang W, Chan RC, Mechelli A, Sweeney JA, Gong Q (2009). High-field MRI reveals an acute impact on brain function in survivors of the magnitude 8.0 earthquake in China. Proc Natl Acad Sci U S A 106(36): 15412-15417. doi: $10.1073 /$ pnas.0812751106

92. Ghadri JR, Sarcon A, Diekmann J, Bataiosu DR, Cammann VL, Jurisic S, Napp LC, Jaguszewski M, Scherff F, Brugger P, Jancke L, Seifert B, Bax JJ, Ruschitzka F, Luscher TF, Templin C, Inter TAKC-i (2016). Happy heart syndrome: role of positive emotional stress in takotsubo syndrome. Eur Heart J 37(37): 2823-2829. doi: 10.1093/eurheartj/ehv757

93. Kalakoski V, Selinheimo S, Valtonen T, Turunen J, Kapykangas S, Ylisassi $H$, Toivio $P$, Jarnefelt $H$, Hannonen $H$, Paajanen $T$ (2020). Effects of a cognitive ergonomics workplace intervention (CogErg) on cognitive strain and well-being: a cluster-randomized controlled trial. A study protocol. BMC Psychol 8(1): 1. doi: 10.1186/s40359-019-03491

94. Ji L, Peng H, Mao X (2019). The role of sensory function in processing speed and working memory aging. Exp Aging Res 45(3): 234251. doi: 10.1080/0361073X.2019.1609168

95. Peng H, Gao Y, Mao X (2017). The roles of sensory function and cognitive load in age differences in inhibition: Evidence from the Stroop task. Psychol Aging 32(1): 42-50. doi: 10.1037/pag0000149

96. Khalili-Mahani N, Smyrnova A, Kakinami L (2019). To each stress its own screen: A cross-sectional survey of the patterns of stress and various screen uses in relation to self-admitted screen addiction. J Med Internet Res 21(4): e11485. doi: 10.2196/11485

97. O'Donnell S, Bird S, Jacobson G, Driller M (2018). Sleep and stress hormone responses to training and competition in elite female athletes. Eur J Sport Sci 18(5): 611-618. doi: 10.1080/17461391.2018.1439535

98. Burroughs Pena MS, Mbassa RS, Slopen NB, Williams DR, Buring JE, Albert MA (2019). Cumulative psychosocial stress and ideal cardiovascular health in older women. Circulation 139(17): 2012-2021. doi: 10.1161/CIRCULATIONAHA.118.033915 